\title{
The Effect of Electronic Word-of-Mouth Communication (e-WOM) on the Conspicuous and Materialist Consumption: Research on Generation Z
}

\author{
Aysel Kurnaz ${ }^{1} \&$ Orhan Duman ${ }^{1}$ \\ ${ }^{1}$ Ömer Seyfettin Faculty of Applied Sciences, Bandırma Onyedi Eylül University, Balıkesir, Turkey \\ Correspondence: Aysel Kurnaz, Ömer Seyfettin Faculty of Applied Sciences, Bandırma Onyedi Eylül University, \\ Balıkesir, Turkey. E-mail: akurnaz@bandirma.edu.tr
}

Received: February 22, 2021

Accepted: March 16, 2021

Online Published: April 11, 2021

doi:10.5539/ijbm.v16n5p103

URL: https://doi.org/10.5539/ijbm.v16n5p103

\begin{abstract}
The aim of this study which derives its generation data from generation $\mathrm{Z}$ is to analyze the effect of electronic word-of-mouth communication (e-WOM) on the conspicuous and materialist consumption. The sample of this study consists of $12^{\text {th }}$ grade students, representing the generation Z, who were born in 2000 and after. Students were selected from a total of 26 high schools in four districts of Balıkesir city in Turkey; districts of Bandirma, Gönen, Erdek and Manyas. A questionnaire was applied to the participants using the convenience sampling method. A total of 1065 questionnaires were found suitable for evaluation. Collected data were analyzed through first-order confirmatory factor analysis and Structural Equation Modeling (SEM). It was concluded at the end of this study that e-WOM communication type triggered a significant and positive effect on conspicuous and materialist consumption.
\end{abstract}

Keywords: e-WOM communication, conspicuous consumption, materialist consumption, generation Z

\section{Introduction}

Generations are generally called silents, baby boomers, and X, Y, Z generations. Those born between 1900-1945 are defined as silent generation. While, those born between 1946-1964 are defined as baby boomer generation and those born between 1965-1979 are defined as generation X. Also, those born between 1980-1999 are generation Y and those born in 2000 and later are known as generation Z or millennials (Kyles, 2005; Murphy, Gordon, \& Anderson, 2004). Generations are composed of individuals whose date of birth coincides with specific years and periods; who adopt certain beliefs and behavioral styles and feel like members of specific groups (Csobanka, 2016). In order to construe modern consumers and development of consumer behaviors among young, it is essential to identify generations born during specific time periods and certain behavioral characteristics they exhibit as consumers (Smola \& Sutton, 2002). Generations X and Y represent those born between 1960 and 2000 and in terms of industrial development the period corresponds to the $3^{\text {rd }}$ Industrial Revolution in which digitalization started to blossom. In the same period using of the electricity, achieved novelties in information and communication technologies as well as automation in manufacturing processes also fueled a differentiation in goods, products and services. As concept of value took the lead, sales development activities gained impetus in order to meet consumer needs and demands.

Born after 2000 members of 'Generation Z', 'Crystal Children', 'Internet Generation', 'Next Generation' consist of consumers who are, compared to their precedents, the most educated, mobile and internet-connected individuals of all ages. In contrast to other generations, those born in this period witnessed a new industrial revolution termed as Industry 4.0. Due to digitalization experienced in manufacturing systems and services, dramatic changes surfaced in consumer demands and thanks to novel technologies it became feasible to respond to these changes more swiftly and effectively, hence services or products could thus become personalized. Consumer demands to discover and experiment what is new and access power of social media turn into a vital constituent in the formation of consumer choices (Buhr, 2017). Members of Generation Z, who also belong to Industry 4.0 period, are likewise socially and technologically aware citizens particularly in pursuit of an innovative and permanent transformation. By favoring written communication forms rather than verbal tools, they are likely to access increased amount of knowledge than older generations (White, 2017). Since they meet 
with technology in quite a young age, they are competent users of technologic tools like the internet, smart phones and social media. Since their childhood they have comfortably reached any information sought on the internet environment. It is reported that generation $\mathrm{Z}$ members feel dependent on social networking sites to communicate, and are largely driven by the celebrities and tend to attach unprecedented value to peer approval (Csobanka, 2016). New technologies can not only empower connectivity and communication of individuals and groups but it can also facilitate the popularity of electronic word-of-mouth communication (e-WOM) (Kauffman \& Panni, 2017).

Based on the strong interest of young people in Turkey towards social media it is accepted that especially the ones born in 2000 and later, so the generation z, which refers to today's youth, are very much in peace with technology and can easily and quickly follow the global developments and trends with the help of social media. Internet and social media usage is the most powerful socialization form for generation Z Currently smart phones allow those youngsters to be actively engaged in listening, viewing, photo/video sharing, commenting on products and brands and viewing and several other areas all in one basket. Thanks to the recent technologic developments in our post-modern consumption society which, due to its intrinsic composition, forms consumer behaviors of generation $\mathrm{Z}$, it is considered that e-WOM communication created a vital influence on their practices. In that regard, since the aim of this study is to underline that communication focus of generation $\mathrm{Z}$ is e-WOM, the analysis dwells on the effect of e-WOM on conspicuous and materialist consumption.

\section{Theoretical Framework}

\subsection{Concepts of Word-of-Mouth Communication (WOM) and Electronic Word-of-Mouth Communication (e-WOM)}

One of the oldest and strongest information-sharing channels among populations since ancient dates (Rui, Liu, \& Whinston, 2010), Word-of-mouth communication (WOM) is defined as a noncommercial and verbal communication form from a sender and receiver on certain products, brands, service or companies (Ismagilova, Dwivedi, Slade, \& Williams, 2017: 7). As specified in this definition three factors are essential to perform WOM. Firstly, there must be physical and real communication among people. Another factor is language itself that is used among the constituents of communication and it encompasses verbal communication. Finally, although communicators deem that WOM lacks any commercial aspect, it can still be argued that in terms of content and offered benefits it may lead to commercial endings too (Nyilasy, 2006). Particularly via WOM communication of satisfied customers who can also be classified as volunteers it is feasible to freely advertise companies, products or services. As the structure of WOM is examined there are five forestaged traits; valence, solicitation, timing, focus and intervention. Valence is explained as defining of WOM communication as positive or negative by a consumer; solicitation refers to acquiring information from another consumer on a product that they deem to be valuable in terms of their interest areas. WOM's timing feature indicates not only pre-shopping communication to direct consumers' purchase-decisions but also entails sharing of consumer experiences by post-shopping communication. Focus, on the other hand, emphasizes that companies should focus on communicating not only with their customers but with all the shareholders of a company. Finally, intervention concept enforces that businesses which acknowledge the power of WOM communication tend to encourage their consumers to share certain products or brands of the company (Buttle, 1998). Based on WOM concept it is detected that while features of valence, solicitation and timing are related with a consumer focus, feature of intervention is related with businesses.

With the domination of social media sites word-of-mouth communication (WOM) evolved into electronic word-of-mouth communication (e-WOM) and provided a widespread and effective source of information in which consumers could freely share their experiences, feelings and opinions (Schau \& Gilly, 2003). In that case e-WOM is defined as positive or negative, biased or unbiased statements that potential, actual or former customers can share and disseminate views on products, goods, services, brands or companies through several internet settings viz. web sites, social networking sites, instant texting and news flows (Hennig-Thurau, Gwinner, Walsh, \& Gremler, 2004; Kietzmann \& Canhoto, 2013). Main characteristics of e-WOM are; enabling communication via different platforms (e-mail, instant texting, blogs, forums, online groups etc.); consumers' ability to access the experiential views of strangers on a product or service thanks to the anonymous and interactive nature of internet, means to view any shared information by anyone in any given time and the capacity to provide information transmission any given time by the rapid flow of information among internet users (Huete-Alcocer, 2017; King, Racherla, \& Bush, 2014; Pan \& Zhang, 2011; C.C. Wang, Yang, \& P. Wang, 2014). Consumers resort to e-WOM communication in order to lower perceived risk and minimize potential losses in decision-making processes (Hussain, Ahmed, Jafar, Rabnawaz, \& Jianzhou, 2017). 
An analysis of relevant literature evidences that a vast majority of studies on e-WOM are directly linked with internet and social media. Innovations, popularity of the internet and technology allow people to form virtual interactions with group members and share their experiences, hence it can be influential on the purchase intentions for their brands and e-WOM dispositions of young consumers that constitute their reference groups (Goldsmith \& Horowitz, 2006). An online survey administered by Chu and Sung (2015) on 175 Twitter-user college students in America concluded that one of the social media domains, Twitter, facilitated e-WOM process. Bataineh and Al-Smadi (2015) in their study used a survey among 367 participants and determined that the level of interest toward social media could be effective on e-WOM. In their study Zhang, Abound Omran and Cabanoglu (2017) maintained that active usage of social media and peer effect caused a strong disposition on generation Y's intentions to share experiential information on a service in e-WOM communication. Survey by Mishra, Maheswarappa, Maity and Samu (2018 a, b) administered among 797 Indian students studying in the 8th and 12th grades revealed that internet usage affected e-WOM dispositions of young. Another study of the same researchers manifested that teenagers who spent longer hours on the internet were more eager to either form or share e-WOM. In a different study aimed at teenagers it was identified that e-WOM effect on social media created a positive influence on consumers' purchase intentions. Once the causes of this effect was unveiled several important factors reached to the surface; attitude towards new information, the need for information, adopting the information, offered benefit of the information for a user, quality and credibility of information (Erkan \& Evans, 2016). Studies on social media marketing evidenced that e-WOM communication and online groups in particular played a crucial role in fueling the intention to purchase by guiding consumer decisions (Balakrishnan, Dahnil, \& Yi, 2014; Shu \& Scott, 2014).

\subsection{Conspicuous Consumption}

Conspicuous consumption concept is established on the theory originally introduced by Veblen (1899) and it was initially equated with the notion of 'leisure' to refer to the aimless free time as a symbol of upper-class lifestyle. This theory puts forth that when a person positions him/herself in a higher rank in social hierarchy as a result of wealth that particular person feels obliged to prove his/her power by exposing possessed riches to others. As evident symbols s/he adopts consumption patterns that can associate the person with upper class while separating from lower class. This conspicuous consumption that transmits abstract concepts like esteem, excellence, luxury, aesthetic and power in a concrete form infuses a meaning and value by evoking respect in a social circle and by abstaining from vulgar consumption modes (Veblen, 2005). Social circle and social identity also play a vital role in conspicuous consumption. In order to climb their social prestige and send messages to others, people purchase the brands and products favored by the members of an upper social class. Thus the person can not only influence his/her social circle but also manage ego satisfaction. There is a stronger tendency for conspicuous consumption among individuals that are most likely to be affected by their social circle and attach high value to social identity (O'Cass \& McEwen, 2004). Since conspicuous consumption can satisfy social needs such as prestige, power, social circle and aspired esteem particulars of a consumed product reach beyond utility and functionality basis and can meet the hedonistic needs of individuals (Podoshen \& Andrzejewski, 2012). In satisfying these needs the effect caused primarily by social networks on the self-images and self-control of individuals should never be ignored. Conducted studies point out that heavy usage of social media can diminish self-control behaviors of consumers and increase their spending on conspicuous products which eventually leading them to exhibit irrational behaviors (Khan \& Dhar, 2006). According to the study of Ismail, Nguyen and Melewar (2018) increased levels of social media usage would positively impact e-WOM, hence this effect could lead to an elevated tendency, particularly among young, for conspicuous consumption. In the same vein, findings of Thoumrungroje (2014) evidenced that e-WOM played a crucial role in individuals' conspicuous consumption dispositions. The moment consumers place their trust in e-WOM the likelihood to consume conspicuous products that can offer a sense of self-esteem also climbs.

\subsection{Materialist Consumption}

Referring to the value and gravity that consumers attribute to material objects (Belk, 1985) the term conceptually originated with the globalization, westernization and transformation of developing oriental countries as mimickers of lifestyles in developed countries and adopting a more consumption-focused society model (Belk, 1985; Ger \& Belk, 1996). Fueled by a desire for a better life, citizens in those countries ascribed to luxury goods (Wong \& Ahuvia, 1998). This movement copied western societies' individualistic way of perception and celebrated material ownership as the focus point of one's life. In response there was a jump in their materialist tendency levels (Schau \& Gilly, 2003). The reason behind high level of materialism is as materials occupy such a major position they can ultimately create satisfaction and/or dissatisfaction in consumers' life directly and/or indirectly. Materialist consumers deem possessing material objects as a tool to attain happiness and they desire to 
hold them as longest as they can. They can express themselves with the goods and objects they possess and present their actual and dreamt identity with their possessions (Belk, 1985; Chang \& Arkin, 2002). In our age materialist consumers are also likely to comment about the products that they experimented within their social circles and social media (Schau \& Gilly, 2003).

In studies focusing on generation $\mathrm{Z}$ consumers of modern age, materialism disposition of teenagers have been presented in several ways. Among young consumers materialism creates a powerful and direct impact with respect to impulsive-purchase orientations among teenagers. Materialism plays a determinant role in the impulsive-purchase tendency of young consumers with an elevated awareness on social self (Xu, 2008). Young consumers equate possessing money with power, prestige and success (Durvasula \& Lysonski, 2010). Among young consumers social media sites provide a favorable communication channel to maintain their relationship with the social circle they hold. Studies reveal that an increase in social media usage corresponds to a jump in favoring materialism and the two variables exhibit a significant and positive correlation (Chu, Windels, \& Kamal, 2016). Teenagers with strong materialist choices tend to shop more and save less and pay interest to the most recent products and react more intensely to advertisements and promotions on the latest products (Goldberg, Gorn, Peracchio, \& Bamossy, 2003).

Conspicuous consumption concept indicates the external motive to influence divisions in a social class, to be part of a social group, to differ from the rest of society and this external motivational source points to a social value. Materialist consumption concept, on the other hand, relates to consumers' personal perceptions towards certain material assets or products and demonstrates itself as a strong will to possess desired materials. To feel contented, consumers resort to materialist consumption to manifest their own identities in effect. That explains why this consumption style represents intrinsic personal values.

\section{Hypotheses Development and Research Model}

Acknowledging that consumers' interest towards social media plays a role in the emergence of e-WOM communication, findings in relevant literature attest that this particular communication method can drive materialist and conspicuous consumption tendencies of young (Chia, 2010; Chu et al., 2016; Ismail et al., 2018; Thoumrungroje, 2014). It can be seen that globalization, developing economies and stages of technological growth led way to certain changes in social structure as well and consequently there was an emergent transformation in behavioral forms and daily shopping routines of consumers. Technological developments at most, easy access to the internet, information and dissemination of data provided noteworthy advantages to consumers. Studies proved that consumers deem internet-based information reliable enough to influence their consumption decisions (Chu \& Kim, 2011; Mishra et al., 2018). The fact that internet users communicate with people they trust on the social media too and initiate interpersonal communication on products paved the way for the rise of e-WOM. In addition, it is detected that via social media, users maintain their good relations with their existing social circle and by contacting with other persons in their social networking, they tend to widen the circle.

Findings of Chia's (2010) study reveal that influence of social media and social circle in effect played a salient role in the materialist values of teenagers. Djafarova and Rushworth (2017) claimed that celebrities on Instagram influenced purchase-behaviors of female consumers and Instagram celebrities were termed as bloggers, YouTubers and 'Instafamous' personas. In the clustering of this influence, such an effect was witnessed since female consumers deemed Instagram celebrities reliable and sincere. In the study of Ferle and Chan (2008) on high-school students it was concluded that via mimicking social media celebrities the media played a positive role in affecting materialist consumption values. As the development of materialist values was compared with respect to generations of adult parents and teenage kids it is seen that in the issue of materialism income level played a determinant role among adults whereas among teenagers the media played role as the key determinant (Gu \& Hung, 2009). In the study of Chu et al. (2016) among college students it was evidenced that a strong correlation existed between intensive use of social media and materialist consumption.

Conducted studies reveal that intensive use of social media played an effective role on conspicuous consumption both directly and by e-WOM. Via e-WOM communication, consumers can have elevated levels of dispositions on consuming conspicuous products that provide a sense of prestige (Thoumrungroje, 2014). It has been observed that among young urban consumers of different cultures there is an upsurge in both materialist and conspicuous consumption (Podoshen, Li, \& Zhang, 2011). According to the findings of Ismail et al.'s (2018) study on Malaysian college students social media usage can, by influencing e-WOM communication, impact teenager's materialist and conspicuous consumption dispositions.

Research model below has been designated on the basis of relevant literature: 


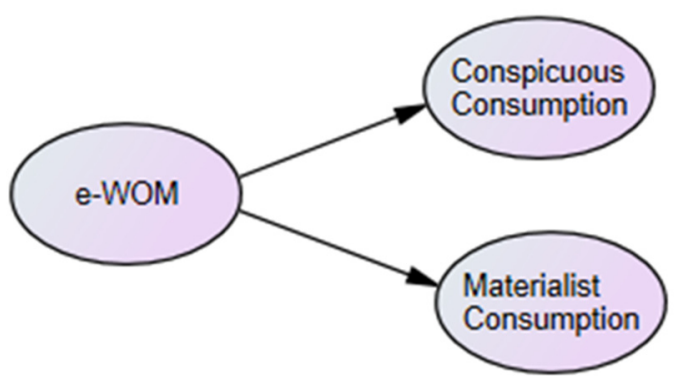

Figure 1. Research model

With the aim of testing the effect of electronic word-of-mouth communication on conspicuous consumption, $\mathrm{H}_{1}$ hypothesis has been suggested in this research model.

$H_{1}$ : e-WOM communication has a positive effect on conspicuous consumption.

With the aim of testing the effect of electronic word-of-mouth communication on materialist consumption, $\mathrm{H}_{2}$ hypothesis has been suggested.

$\mathrm{H}_{2}$ : e-WOM communication has a positive effect on materialist consumption.

\section{Methodology}

\subsection{Sample and Procedure}

It is important to identify the e-WOM communication of young people in the generation $\mathrm{Z}$ dispositions towards conspicuous consumption that is more easily viewable by others through the social media tools and evermore growth within a consumption society collectively play a critical role in the need to reveal their materialist disposition. From this point of view, people born in 2000 and later, corresponding to the generation Z, constitute the main mass of this study. Therefore, the sample of this study consists of 12th grade (senior) students who are studying in a total of 26 high schools located in four districts of Balıkesir city in Turkey; Bandırma, Gönen, Erdek and Manyas respectively. The questionnaire created within the scope of the study was applied to the people who volunteered to participate in the study. Due to the cost and time constraints that may be experienced in reaching these people, convenience sampling method was used. A pilot application was carried out on 20 people within the scope of the sample in order to ensure the comprehension of the questions before the structural questionnaire was delivered to the participants. As a result of the pilot application, the questionnaire was finalized. After excluding incomplete and incorrect surveys, a total of 1065 questionnaire were accepted to be fit for the analysis. Distribution of participants as per districts of Balıkesir is shown in Table 1.

Table 1. Distribution of Participants as per Districts

\begin{tabular}{lcc}
\hline District & Frequency & \% \\
\hline Bandırma & 476 & 44.9 \\
Gönen & 458 & 42.9 \\
Erdek & 72 & 6.7 \\
Manyas & 59 & 5.5 \\
Total & 1065 & 100 \\
\hline
\end{tabular}

Considering that gender-based distribution of population is nearly equal in Turkey $54 \%$ were female while $46 \%$ were female students among all the participating students, thus a balanced distribution was achieved with respect to gender.

In addition, the data used in the study were collected with the support of the Balıkesir City Bandirma Guidance and Research Center affiliated to Republic of Turkey Ministry of Education. Guidance and Research Centers conduct studies for the effective implementation of guidance and psychological counseling services for students and their families in educational institutions. This institution is also responsible for the educational evaluation of students. 


\subsection{Measurement}

Research survey-form consists of 3 sections that contain demographical features of participants and their statements on e-WOM communication, conspicuous and materialist consumption variables. To measure teenagers' e-WOM communication level, the scale developed by Thoumrungroje (2014) on the basis of Bearden, Netemeyer and Teel's (1989) study with 6 statements was employed. 'Conspicuous consumption' scale on the other hand was developed by Chung and Fisher (2001) and consisted of 4 statements. To measure teenagers' dispositions towards materialist consumption, the scale developed by Richins and Dawson (1992) being verified in relevant literature was harnessed. Materialist consumption variable was measured with 7 statements. In order to determine teenagers' agreement level with the statements in e-WOM communication, conspicuous and materialist consumption scale, 5-point (1: I completely disagree ... 5: I completely agree) Likert scale was utilized.

\section{Results}

\subsection{Results of Measurement Model}

In order to analyze research model and test the interrelation of variables in the model for the aim of revealing to what extend these variables represent relevant structures, first of all, first order confirmatory factor analysis was administered on the measurement model. In that sense it was aimed to test measurement model in regard to reliability and validity as well.

At the end of confirmatory factor analysis, by excluding statements that fail to sufficiently explain dimensions of each variable, modifications suggested in the analysis could be actualized. Upon conducting required modifications, it was validated that e-WOM variable was explained by five statements and standardized regression coefficients of the statements fluctuated between 0.683 and 0.823 . Standardized regression coefficients of four statements of conspicuous consumption variable changed between 0.671 and 0.755 while standardized regression coefficients of seven statements in materialist consumption varied between 0.501 and 0.698. Values of good-fit indices (Byrne, 2010) regarding the confirmatory factor analysis of measurement model revealed that the model had good fit and obtained values were in acceptable levels ( $\chi 2 /$ df: 3.307 GFI: 0.963 AGFI: 0.948 CFI: 0.963 TLI: 0.954 RMSEA: 0.047).

Confirmatory factor analysis of measurement model provided good-fit values and reliability and validity analyses of the variables were then performed. To provide reliability and construct validity of the structures CR, AVE and Cronbach's Alpha values were examined. To prove reliability, it was expected for Cronbach's Alpha value to exceed 0.70 limit, CR (Composite Reliability) value to be higher than 0.70 and AVE (Average Variance Extracted) value to be above 0.50 (Fornell \& Larcker, 1981; Hair, Anderson, Tatham, \& Black, 1998). It is detected that Cronbach's Alpha and CR values of three variables in measurement model were above 0.70. AVE values however were above 0.50 among e-WOM and conspicuous consumption variable but in materialist consumption variable this value was measured to be below 0.50. Fornell and Larcker (1981) claimed that if other reliability criteria are met, it is permitted to accept AVE's values below 0.50, it is safe to claim that reliability was achieved in all variables.

For convergent validity it is accepted AVE value to be above 0.50 and CR value to be above AVE value (Hair et al., 1998). It is detected that all of the variables in measurement model possessed CR values that were bigger than AVE values. As argued before, for AVE values, only the value for materialist consumption variable was below 0.50 but it was still an acceptable value. It can thus be argued that convergent validity of the measurement model could be achieved.

Standardized regression and coefficients of error, Cronbach's Alpha, CR and AVE values of all variables in measurement model are as outlined in Table 2 below. 
Table 2. Results of confirmatory factor analysis

\begin{tabular}{|c|c|c|c|c|c|}
\hline Scale items & $\begin{array}{l}\text { Standardized } \\
\text { loading } \\
(\lambda)\end{array}$ & $\begin{array}{c}\text { Error } \\
\text { coefficients (e) }\end{array}$ & $\alpha^{*}$ & $C R * *$ & $A \boldsymbol{V E} \boldsymbol{E}^{* * *}$ \\
\hline Electronic Word-of-Mouth & & & 0.88 & 0.87 & 0.57 \\
\hline $\begin{array}{l}\text { WOM2. I usually talk to my contacts on the social } \\
\text { networking site before I buy products. }\end{array}$ & 0.685 & 0.530 & & & \\
\hline $\begin{array}{l}\text { WOM3. I like to get the opinions of my contacts on the } \\
\text { social networking site before I buy products. }\end{array}$ & 0.746 & 0.443 & & & \\
\hline $\begin{array}{l}\text { WOM4. I often ask my contacts on the social networking } \\
\text { site about what products to buy. }\end{array}$ & 0.728 & 0.470 & & & \\
\hline WOM5. I feel more comfortable choosing products when & & & & & \\
\hline $\begin{array}{l}\text { I have gotten opinions from my contact on the social } \\
\text { networking site. }\end{array}$ & 0.816 & 0.335 & & & \\
\hline $\begin{array}{l}\text { WOM6. When choosing products, my contact's opinions } \\
\text { on the social networking site are important to me. } \\
\text { Conspicuous Consumption }\end{array}$ & 0.775 & 0.399 & & & \\
\hline $\begin{array}{l}\mathrm{CC} 1 \text {. It is important to know what friends think of } \\
\text { different brands or products I am considering. }\end{array}$ & 0.713 & 0.492 & 0.80 & 0.81 & 0.52 \\
\hline $\begin{array}{l}\text { CC2. It is important to know what kinds of people buy } \\
\text { brands or products I am considering. }\end{array}$ & 0.731 & 0.466 & & & \\
\hline $\begin{array}{l}\text { CC3. It is important to know what others think of people } \\
\text { who use certain brands or products I am considering. }\end{array}$ & 0.709 & 0.498 & & & \\
\hline $\begin{array}{l}\text { CC4. It is important to know what brands or products to } \\
\text { buy to make a good impression on others. }\end{array}$ & 0.717 & 0.486 & & & \\
\hline Materialist Consumption & & & & & \\
\hline $\begin{array}{l}\text { MC1. I would be happier if I could afford to buy more } \\
\text { things. }\end{array}$ & 0.512 & 0.738 & & & \\
\hline MC2. It sometimes bothers me quite a bit that I can't & 0.509 & 0.741 & & & \\
\hline afford to buy all the things I'd like. & & & 0.77 & 0.76 & 0.31 \\
\hline $\begin{array}{l}\text { MC3. I admire people who own expensive homes, cars } \\
\text { and clothes. }\end{array}$ & 0.553 & 0.694 & & & \\
\hline $\begin{array}{l}\text { MC4. Some of the most important achievements in life } \\
\text { include acquiring material possessions. }\end{array}$ & 0.541 & 0.708 & & & \\
\hline MC5. I like to own things that impress people. & 0.574 & 0.671 & & & \\
\hline MC6. Buying things gives me a lot of pleasure. & 0.513 & 0.737 & & & \\
\hline MC7. I like a lot of luxury in my life. & 0.672 & 0.548 & & & \\
\hline
\end{tabular}

Note. ${ }^{*} \alpha$ : Cronbach alpha ${ }^{* *}$ Composite Reliability: $(\Sigma \lambda)^{2} /(\Sigma \lambda)^{2}+\Sigma \mathrm{e} .{ }^{* * *}$ Average Variance Extracted: $\Sigma \lambda^{2} / \Sigma \lambda^{2}+\Sigma \mathrm{e}$ and $\mathrm{e}=1-\lambda^{2}$.

Via administering discriminant validity, it is aimed to analyze if structures in the model are distinct structures. By fixing correlations among the dimensions in measurement model in 1 it was aimed to test 'unrestricted model' in which correlations are freed against a 'restricted model' (Bagozzi, Yi, \& Phillips, 1991). Results of the analysis of discriminant validity are as tabulated in Table 3.

Table 3. Results of discriminant validity

\begin{tabular}{lcc}
\hline Models & $\chi^{2}$ & Degree of freedom (df) \\
\hline Model 1 (Correlations fixed at 1) & 577.810 & 99 \\
Model 2 (Correlations free) & 317.471 & 96 \\
$\Delta \chi^{2}$ & 260.339 & \\
$\Delta$ Degree of freedom (df) & & 3 \\
\hline
\end{tabular}

According to Table 3 , the critical value of 3 degrees of freedom is 7.815 and $\Delta \chi 2=260.339>\chi 23 ; 0.05=7.815$, 
discriminant validity of the model was achieved.

Discriminant validity was also evaluated within the scope of the criteria proposed by Fornell and Larcker (1981). According to this criterion, the square root of the AVE (Average Variance Extracted) values of the structures in the measurement model must be higher than the correlations between the structures. When Table 4 is examined, it can be said that the discrimination validity of the structures is realized by providing this situation.

Table 4. Correlation Matrix between Structures

\begin{tabular}{lccc}
\hline & e-WOM & $\begin{array}{c}\text { Conspicuous } \\
\text { Consumption }\end{array}$ & $\begin{array}{c}\text { Materialist } \\
\text { Consumption }\end{array}$ \\
\hline e-WOM & 0.754 & - & - \\
Conspicuous Consumption & 0.457 & 0.721 & - \\
Materialist Consumption & 0.297 & 0.542 & 0.556 \\
\hline
\end{tabular}

\subsection{Testing the Research Hypotheses}

Upon the validity and reliability analyses of findings of confirmatory factor analysis on the measurement model consisting of variables such as e-WOM communication, conspicuous and materialist consumption variables, structural equation model was commenced.

At the end of this analysis it was detected that the good-fit indices of the analyzed model provided satisfactory results ( $\chi 2$ /df: 4.716; GFI: 0.948; AGFI: 0.927; CFI: 0.940; TLI: 0.925; RMSEA: 0.059). Based on predicted structural coefficients, explanatoriness and significance levels of the variables in structural model it was provided in Table 5 whether or not research hypotheses were accepted.

Table 5. Standardized regression coefficient and the results of hypotheses testing

\begin{tabular}{lccccc}
\hline & $\begin{array}{c}\text { Standardized } \\
\text { regression } \\
\text { coefficient }\end{array}$ & $\mathbf{R}^{2}$ & C.R.* & $\begin{array}{c}\text { Sig. } \\
(\mathbf{P})\end{array}$ & Result \\
\hline $\mathrm{e}-\mathrm{WOM} \longrightarrow$ Conspicuous C. & 0.480 & 0.229 & 11.797 & $* * *$ & $\mathrm{H}_{1}$ Accepted \\
$\mathrm{e}-\mathrm{WOM} \longrightarrow$ Materialist C. & 0.331 & 0.110 & 7.715 & $* * *$ & $\mathrm{H}_{2}$ Accepted \\
\hline Note. ${ }^{*}$ C.R.: Critical Ratio. & & & & &
\end{tabular}

As findings of structural equation model in Table 5 were evaluated it surfaced that e-WOM communication created a relatively greater effect on conspicuous consumption $(0.480)$. It was followed by a materialist consumption variable (0.331). As the effect of e-WOM communication on conspicuous consumption and materialist consumption was analyzed, the effect was found to be positive and significant; thus hypotheses $\mathrm{H}_{1}$ and $\mathrm{H}_{2}$ were accepted.

\section{Conclusion}

The aim of this study is to express relative effect of social-media-driven e-WOM communication on the tendency of conspicuous and materialist consumption. In accordance with this aim, understanding and analyzing generation $\mathrm{Z}$ that describe teenagers and behavioral forms of our modern consumption society can offer vital clues on the future of digital life. It is obvious that this generation is influenced by their peers' or particularly by social media celebrities in their consumption choices. Senior high-school students that correspond to generation $\mathrm{Z}$ constituted the sample of this research.

In the stage of analyzing collected data, initially, first-order confirmatory factor analysis was administered separately for each of the variable of e-WOM communication, conspicuous and materialist consumption variables. Upon the necessary changes after the analysis Cronbach's Alpha, CR and AVE values were achieved for the reliability and convergent validity of every single variable. To test the hypothesis after achieving good-fit, construct validity and reliability of the model structural equation model was administered on the data. When the findings were evaluated after structural equation, it was determined that e-WOM communication offered statistically significant and positive effects on conspicuous and materialist consumption thus $\mathrm{H}_{1}$ and $\mathrm{H}_{2}$ 
hypotheses were accepted. Findings of our study are in parallel with relevant findings in literature (Chia, 2010; Chu et al., 2016; Gu \& Hung, 2009; Ismail et al., 2018; Podoshen et al., 2011; Thoumrungroje, 2014).

It was also ascertained that e-WOM communication of teenagers in generation $\mathrm{Z}$ had a relatively greater effect on their conspicuous consumption. As the motives underlying the causes of conspicuous consumption are examined, it surfaces that personal desire to ego satisfaction, aim to elevate one's social prestige, raise reputation in one's social circle by sharing a social message are some of these motives. As this consumption style is examined in terms of teenagers it is viewed teenagers get engaged in conspicuous consumption as a symbol of belonging with groups they feel attached or to distinguish themselves from groups they want to be detached (Eastman, Goldsmith, \& Flynn, 1999; Sheth, Newman, \& Gross, 1991). As argued by Veblen in theory of 'conspicuous consumption' teenagers in generation $\mathrm{Z}$ can, by practicing conspicuous consumptions, find a chance to distinguish themselves from other personas. Further to that among some of the social circles possessing certain brands, product or services is viewed as symbol of achievement and power. In that sense those individuals manage to achieve their social circle positively and these teenagers attract all the attention by being eminent among their peers or social circle. For generation $\mathrm{Z}$ that stands for teenagers of our modern digital world, practicing conspicuous consumption becomes much faster and easier on the internet or social media. During decision-making process on a given product, brand or service teenagers trust more celebrities on social media, friends or total strangers that form their online social circle and as a result of their young age they are significantly guided by their comments or suggestions. In that way they can expose their social-self with the selected products and be member of the social circle they feel like belonging to.

Another finding of this research, that e-WOM communication had a positive and significant effect on materialist consumption, can be explained with the motive of individuals to place extreme value on material objects just to forge their identities and manifest their existence. Underlying reason of the extreme attachment of individuals with material assets is, in addition to emotional or symbolic meanings ascribed to these products (Belk, 1985), related to one's desire for social status and an empowered self. It is also attested that individuals with strong materialist values tend to consume more (Goldberg et al., 2003; Lynn \& Haris, 1997). As teenagers get older in particular, there is an enhanced degree of disposition towards possessing certain products or brands, elevated desire to consume and likelihood to be more influenced by their social circle (Torlak \& Ay, 2014). People with materialist tendencies compare themselves with others and their possessions mean an incredibly high value at this point. For those with strong materialist values possessing or lacking a material asset brings with itself satisfaction or dissatisfaction with life. Since generation $\mathrm{Z}$ teenagers were born into a consumption society and never lived in a world without internet, they attach dramatic value to instant and immediate satisfactions. By being present in social media, generation $\mathrm{Z}$ can actualize their identity to their self-content and demonstrate their identities. Members of this generation can be exemplified with the findings of Simmel's study that examined state of individuals after the uprise of cities. Social media and similar virtual environments enable people to create 'false identities' and in such environments people can freely expose their material possessions. As this happens their inner-driven personal values can be fed and some sort of satisfaction can be gained.

As the results are evaluated as a whole it can be argued that the reason for e-WOM communication to create a greater effect on conspicuous consumption compared to materialist consumption is that for teenagers of generation $\mathrm{Z}$, a social circle consisted of friends, groups that they care about and social media celebrities can have a wider influence. It is detected that in the emergence of this condition the event that motivates generation $\mathrm{Z}$ towards conspicuous consumption involves an external social phenomenon and consumers of this age attribute major value to this social phenomenon. From that viewpoint it can be argued that for the members of generation $\mathrm{Z}$ the effect of social values is comparatively stronger than satisfying one's personal values in forming an e-WOM communication.

\subsection{Suggestions for Future Research}

There was a limitation since data for this research were collected only from 4 districts of Balıkesir city namely Bandırma, Gönen, Erdek and Manyas with the assistance of Bandırma Counseling and Research Center as the responsible institute. Another limitation of the study is that since data were collected instantly and in one-time only from participants, the potential dispositions were most likely ignored.

Since generation $\mathrm{Z}$ analyzed as the sample of this study will be the consumers with a potential to purchase in the future it is of utmost importance for marketing practitioners in particular to comprehend and interpret behavioral forms, lifestyles and consumption dispositions of this generation. It is thus suggested that future studies analyze further consumption dispositions of $\mathrm{X}$ and $\mathrm{Y}$ generations in order to determine and contrast key similarities and differences among generations. Another suggestion is that since findings offered in this study relate to the 
intensity of internet and social media users in Turkey, the said variables could be evaluated with respect to other cultures as well.

\section{References}

Bagozzi, R. P., Yi, Y., \& Phillips, L. W. (1991). Assessing construct validity in organizational research. Administrative Science Quarterly, 36, 421-458. https://doi.org/10.2307/2393203

Balakrishnan, B. K., Dahnil, M. I., \& Yi, W. J. (2014). The impact of social media marketing medium toward purchase intention and brand loyalty among generation Y. Procedia-Social and Behavioral Sciences, 148, 177-185. https://doi.org/10.1016/j.sbspro.2014.07.032

Bataineh, A. Q., \& Al-Smadi, H. M. (2015). Factors impact customers engagement in e-WOM on SNSS of non-profit organizations: The moderating role of habit. International Journal of Business and Management, 10(6), 178. https://doi.org/10.5539/ijbm.v10n6p178

Bearden, W. O., Netemeyer, R. G., \& Teel, J. E. (1989). Measurement of consumer susceptibility to interpersonal influence. Journal of Consumer Research, 15(4), 473-481. https://doi.org/10.1086/209186

Belk, R. W. (1985). Materialism: Trait aspects of living in the material world. Journal of Consumer Research, 12(3), 265-80. https://doi.org/10.1086/208515

Buhr, D. (2017). Social innovation policy for industry 4.0. Germany: Friedrich-Ebert-Stiftung.

Buttle, F. A. (1998). Word of mouth: Understanding and managing referral marketing. Journal of Strategic Marketing, 6(3), 241-254. https://doi.org/10.1080/096525498346658

Byrne, B. M. (2010). Structural equation modeling with AMOS. New York: Taylor and Francis Group.

Chia, S. C. (2010). How social influence mediates media effects on adolescents materialism. Communication Research, 37(3), 400-419. https://doi.org/10.1177/0093650210362463

Chang, L., \& Arkin, R. M. (2002). Materialism as an attempt to cope with uncertainty. Psychology and Marketing, 19(5), 389-406. https://doi.org/10.1002/mar.10016

Chu, S. C., Windels, K., \& Kamal, S. (2016). The influence of self-construal and materialism on social media intensity: A study of China and The United States. International Journal of Advertising, 35(3), 569-588. https://doi.org/10.1080/02650487.2015.1068425

Chu, S. C., \& Kim, Y. (2011). Determinants of consumer engagement in electronic word-of-mouth (e-WOM) in social networking sites. International Journal of Advertising, 30(1), 47-75. https://doi.org/10.2501/IJA-30-1-047-075

Chu, S. C., \& Sung, Y. (2015). Using a consumer socialization framework to understand electronic word-of-mouth (e-WOM) group membership among brand followers on twitter. Electronic Commerce Research and Applications, 14(4), 251-260. https://doi.org/10.1016/j.elerap.2015.04.002

Chung, E., \& Fischer, E. (2001). When conspicuous consumption becomes inconspicuous: The case of the migrant Hong Kong consumers. Journal of Consumer Marketing, 18(6), 474-487. https://doi.org/10.1108/07363760110404378

Csobanka, Z. E. (2016). The Z generation. Acta Technologica Dubnicae, 6(2), 63-76. https://doi.org/10.1515/atd-2016-0012

Djafarova, E., \& Rushworth, C. (2017). Exploring the credibility of online celebrities; instagram profiles in influencing the purchase decisions of young female users. Computers in Human Behavior, 68, 1-7. https://doi.org/10.1016/j.chb.2016.11.009

Durvasula, S., \& Lysonski, S. (2010). Money, money, money-How do attitudes toward money impact vanity and materialism? The case of young Chinese consumers. Journal of Consumer Marketing, 27(2), 169-179. https://doi.org/10.1108/07363761011027268

Eastman, J. K., Goldsmith, R. E., \& Flynn, L.R. (1999). Status consumption in consumer behavior: Scale development and validation. Journal of Marketing Theory and Practice, 7, 41-52. https://doi.org/10.1080/10696679.1999.11501839

Erkan, I., \& Evans, C. (2016). The influence of e-WOM in social media on consumers' purchase intentions: An extended approach to information adoption. Computers in Human Behavior, 61, 47-55. https://doi.org/10.1016/j.chb.2016.03.003 
Ferle, C. L., \& Chan, K. (2008). Determinants for materialism among adolescents in Singapore. Young Consumers, 9(3), 201-214. https://doi.org/10.1108/17473610810901633

Fornell, C., \& Larcker, D. (1981). Evaluating structural equation models with unobservable variables and measurement error. Journal of Marketing Research. 18(1), 39-50. https://doi.org/10.1177/002224378101800104

Ger, G., \& Belk, R. W. (1996). Cross-cultural differences in materialism. Journal of Economic Psychology, 17(1), 55-77. https://doi.org/10.1016/0167-4870(95)00035-6

Goldberg, M. E., Gorn, G. J., Peracchio, L. A., \& Bamossy, G. (2003). Understanding materialism among youth. Journal of Consumer Psychology, 13(3), 278-288. https://doi.org/10.1207/S15327663JCP1303_09

Goldsmith, R. E., \& Horowitz, D. (2006). Measuring motivations for online opinion seeking. Journal of Interactive Advertising, 6(2), 1-16. https://doi.org/10.1080/15252019.2006.10722114

Gu, F. F., \& Hung, K. (2009). Materialism among adolescents in China: A historical generation perspective. Journal of Asia Business Studies, 3(2), 56-64. https://doi.org/10.1108/15587890980000411

Hair, J., Anderson, R., Tatham, R., \& Black, W. (1998). Multivariate data analysis (5th ed.). Upper Saddle River, NY: Prentice-Hall.

Hennig-Thurau, T., Gwinner, K. P., Walsh, G., \& Gremler, D. D. (2004). Electronic word-of-mouth via consumer-opinion platforms: What motivates consumers to articulate themselves on the internet? Journal Interact Market, 18(1), 38-52. https://doi.org/10.1002/dir.10073

Huete-Alcocer, N. (2017). A literature review of word of mouth and electronic word of mouth: Implications for consumer behavior. Frontiers in Psychology, 8, 1256. https://doi.org/10.3389/fpsyg.2017.01256

Hussain, S., Ahmed, W., Jafar, R. M. S., Rabnawaz, A., \& Jianzhou, Y. (2017). e-WOM source credibility, perceived risk and food product customer's information adoption. Computers in Human Behavior, 66, 96-102. https://doi.org/10.1016/j.chb.2016.09.034

Ismail, A. R., Nguyen, B., \& Melewar, T. C. (2018). Impact of perceived social media marketing activities on brand and value consciousness: Roles of usage, materialism and conspicuous consumption. International Journal of Internet Marketing and Advertising, 12(3), 233-254. https://doi.org/10.1504/IJIMA.2018.093387

Ismagilova, E., Dwivedi, Y. K., Slade, E., \& Williams, M. D. (2017). Electronic word of mouth (e-WOM) in the marketing context: A state of art analysis and future directions. Springer Briefs in Business, 1-138. https://doi.org/10.1007/978-3-319-52459-7

Kaufmann, H. R., \& Panni, M. F. K. P. (2017). Socio-Economic perspectives on consumer engagement and buying behavior. The United States of America: IGI Global. https://oi.org/10.4018/978-1-5225-2139-6

Khan, U., \& Dhar, R. (2006). Licensing effect in consumer choice. Journal of Marketing Research, 43(2), 259-266. https://doi.org/10.1509/jmkr.43.2.259

Kietzmann, J., \& Canhoto, A. (2013). Bittersweet! Understanding and managing electronic word of mouth. Journal of Public Affairs, 13(2), 146-159. https://doi.org/10.1002/pa.1470

King, R. A., Racherla, P., \& Bush, V. D. (2014). What we know and don't know about online word-of-mouth: A review and synthesis of the literature. Journal of Interactive Marketing, 28(3), 167-183. https://doi.org/10.1016/j.intmar.2014.02.001

Kyles, D. (2005). Managing your multigenerational workforce. Strategic Finance, 87(6), 52-55.

Lynn, M., \& Harris, J. (1997). The desire for unique consumer products: A new individual differences scale. $\begin{array}{llll}\text { Psychology } \quad \text { and } & \text { Marketing. }\end{array}$ https://doi.org/10.1002/(SICI)1520-6793(199709)14:6<601::AID-MAR5>3.0.CO;2-B

Mishra, A., Maheswarappa, S. S., Maity, M., \& Samu, S. (2018a). Teenagers' e-WOM intentions: A nature vs nurture perspective. Marketing Intelligence \& Planning, 36(4), 470-483. https://doi.org/10.1108/MIP-09-2017-0186

Mishra, A., Maheswarappa, S. S., Maity, M., \& Samu, S. (2018b). Adolescent's e-WOM intentions: An investigation into the roles of peers, the internet and gender. Journal of Business Research, 86, 394-405. https://doi.org/10.1016/j.jbusres.2017.04.005

Murphy, E. F., Gordon, J. D., \& Anderson, T. L. (2004). Cross-cultural, cross-cultural age and cross-cultural generational differences in values between the United States and Japan. Journal of Applied Management 
and Entrepreneurship, 9, 21-47.

Nyilasy, G. (2006). Word of mouth: What we really know and what we don't'. Connected Marketing, 161-184.

O'Cass, A., \& McEwen, H. (2004). Exploring consumer status and conspicuous consumption. Journal of Consumer Behaviour, 4(1), 25-39. https://doi.org/10.1002/cb.155

Pan, Y., \& Zhang, J. Q. (2011). Born unequal: A study of the helpfulness of user-generated product reviews. $J$ Retail, 87(4), 598-612. https://doi.org/10.1016/j.jretai.2011.05.002

Podoshen, J. S., Li, L., \& Zhang, J. (2011). Materialism and conspicuous consumption in China: A cross-cultural examination. International Journal of Consumer Studies, 35, 17-25. https://doi.org/10.1111/j.1470-6431.2010.00930.x

Podoshen, J. S., \& Andrzejewski, S. A. (2012). An examination of the relationships between materialism, conspicuous consumption, impulse buying and brand loyalty. Journal of Marketing Theory and Practice, 20(3), 319-333. https://doi.org/10.2753/MTP1069-6679200306

Richins, M., \& Dawson, S. (1992). A consumer values orientation for materialism and its measurement: Scale development and validation. Journal of Consumer Research, 19, 303-316. https://doi.org/10.1086/209304

Rui, H., Liu, Y., \& Whinston, A. B. (2010). Chatter matters: How twitter can open the black box of online word-of-mouth. In ICIS, 204.

Schau, H. J., \& Gilly, M. C. (2003). We are what we post? Self-presentation in personal web space. Journal of Consumer Research, 30, 385-404. https://doi.org/10.1086/378616

Sheth, J. N., Newman, B. I., \& Gross, B. L. (1991). Consumption values and market choice. Cincinnati, Ohio: South Western Publishing.

Shu, M., \& Scott, N. (2014). Influence of social media on chinese students' choice of an overseas study destination: An information adoption model perspective. Journal of Travel ve Tourism Marketing, 31(2), 286-302. https://doi.org/10.1080/10548408.2014.873318

Smola, K. W., \& Sutton, C. (2002). Generational differences: Revisiting generational work values for the new millennium. Journal of Organizational Behavior, 23, 363-382. https://doi.org/10.1002/job.147

Thoumrungroje, A. (2014). The influence of social media intensity and e-wom on conspicuous consumption. Procedia - Social and Behavioral Science, 148, 7-15. https://doi.org/10.1016/j.sbspro.2014.07.009

Torlak, Ö., \& Ay, U. (2014). The relationship between purpose of using facebook and interest with facebook ads. Anadolu University Journal of Social Sciences, 14(4), 83-94.

Veblen, T. (1899). The theory of the leisure class. New York: New American Library.

Veblen, T. (2005). Aylak sinıfin teorisi (1st ed.). İstanbul: Babil Yayınları.

Wang, C. C., Yang, Y. Y. H., \& Wang, P. (2014). Sharing word-of-mouths or not: The difference between independent and interdependent self-construal. in PACIS 2014; Paper Presented at the Proceedings-Pacific Asia Conference on Information Systems, Chengdu, China, 24-28 June 2014.

White, J. E. (2017). Meet generation Z: Understanding and reaching the new post-christian world. Grand Rapids: Baker Publications Group, Grand Rapids, Michigan.

Wong, N. Y., \& Ahuvia, A. C. (1998). Personal taste and family face: Luxury consumption in confucian and western societies. Journal of Psychology \& Marketing, 15(5), 423-441. https://doi.org/10.1002/(SICI)1520-6793(199808)15:5<423::AID-MAR2>3.0.CO;2-9

$\mathrm{Xu}, \mathrm{Y}$. (2008). The influence of public self-consciousness and materialism on young consumers' compulsive buying. Young Consumers, 9(1), 37-48. https://doi.org/10.1108/17473610810857309

Zhang, T., Abound Omran, B., \& Cobanoglu, C. (2017). Generation y's positive and negative eWOM: Use of social media and mobile technology. International Journal of Contemporary Hospitality Management, 29(2), 732-761. https://doi.org/10.1108/IJCHM-10-2015-0611

\section{Copyrights}

Copyright for this article is retained by the author(s), with first publication rights granted to the journal.

This is an open-access article distributed under the terms and conditions of the Creative Commons Attribution license (http://creativecommons.org/licenses/by/4.0/). 